\title{
Contrasting Impacts of Three Extreme El Niños on Double ITCZs over the Eastern Pacific Ocean
}

\author{
Yinlan Chen ${ }^{1,2}$, Li Yan ${ }^{1,2, * \mathbb{C}},{\text { Gen } \mathrm{Li}^{3}{ }^{1} \text {, Jianjun } \mathrm{Xu}^{1,2} \text {, Jingchao Long }}^{1,2}$ and Shaojun Zheng ${ }^{1,2}$ \\ 1 South China Sea Institute of Marine and Meteorology, College of Ocean and Meteorology, \\ Guangdong Ocean University, Zhanjiang 524088, China; chenylan@gdou.edu.cn (Y.C.); \\ gmuxujj@163.com (J.X.); longjc@gdou.edu.cn (J.L.); zhengsj@gdou.edu.cn (S.Z.) \\ 2 Southern Marine Science and Engineering Guangdong Laboratory, Marine Resources Big Data Center of \\ South China Sea, Zhanjiang 524000, China \\ 3 Key Laboratory of Marine Hazards Forecasting, Ministry of Natural Resources, College of Oceanography, \\ Hohai University, Nanjing 210098, China; ligen@hhu.edu.cn \\ * Correspondence: gmuyanli@163.com
}

check for updates

Citation: Chen, Y.; Yan, L.; Li, G.; Xu, J.; Long, J.; Zheng, S. Contrasting Impacts of Three Extreme El Niños on Double ITCZs over the Eastern Pacific Ocean. Atmosphere 2021, 12, 424. https://doi.org/10.3390/ atmos12040424

Academic Editors: Youmin Tang, Xiaoxiao Tan and Satyaban Bishoyi Ratna

Received: 14 February 2021

Accepted: 22 March 2021

Published: 26 March 2021

Publisher's Note: MDPI stays neutral with regard to jurisdictional claims in published maps and institutional affiliations.

Copyright: (c) 2021 by the authors. Licensee MDPI, Basel, Switzerland. This article is an open access article distributed under the terms and conditions of the Creative Commons Attribution (CC BY) license (https:/ / creativecommons.org/licenses/by/ $4.0 /)$.

\begin{abstract}
In the recent four decades, there were three record-breaking El Niño events: 1982/1983, 1997/1998, and 2015/2016 events. A double intertropical convergence zone (ITCZ) pattern distinctively emerges over the eastern Pacific Ocean during boreal spring. Based on reanalysis (ERA-Interim) during 1979-2018, this study examines how these three extreme El Niños modulate such double ITCZs. The 1982/1983 and 1997/1998 El Niños moved both northern and southern ITCZs equatorward to form an individual and broad equatorial ITCZ. In contrast, the regulation of 2015/2016 El Niño was unique with a strengthened southern ITCZ to form a symmetric double-ITCZ. The above differences can be attributed to the different meridional structures of sea surface temperatures (SSTs). For the 1982/1983 and 1997/1998 El Niños, there was a meridionally symmetric structure of SST warming with a maximum at the equator. While for 2015/2016 El Niño, there was a meridionally symmetric structure of SST warming with a minimum at the equator.
\end{abstract}

Keywords: extreme El Niño events; double ITCZs; meridional structure of SSTs; eastern Pacific Ocean

\section{Introduction}

El Niño-Southern Oscillation (ENSO) is the strongest inter-annual mode of air-sea interaction in the tropical Pacific Ocean. In the recent four decades, there have been three record-breaking El Niño events: 1982/1983, 1997/1998, and 2015/2016 events. All three events can be classified as eastern Pacific-type (EP-type) El Niños (Figure 1). Their magnitudes (estimated by Niño-3 value) are comparable, all exceeding two standard deviations during winter (Figure 1). Besides these similarities, they also exhibit event-toevent differences, particularly for the recent 2015/2016 event [1,2]. Compared with the two previous extreme events, the 2015/2016 event had weaker warming off the South American coast $[3,4]$. Westerly wind bursts (WWBs) and the ocean heat content preconditioning both favored this 2015/2016 event [5,6]. In comparison to the 1982/1983 and 1997/1998 events, the 2015/2016 event displayed a shallower thermocline and decays faster [3,7].

The intertropical convergence zone (ITCZ) has important local and remote climate impacts. The ITCZ can be identified by deep convection [8] and intense rainfall [9,10]. ITCZ tends to locate on the warmest sea surface temperature (SST). Its maintenance is related to the wind-evaporation-SST (WES) mechanism [11] and the stratus-SST feedbacks [9]. At most times of a year, the ITCZ appears as an individual belt of heavy precipitation, located in the northern hemisphere (Figure 2a). In March-April, a unique double-ITCZ pattern can emerge over the eastern Pacific Ocean [10,12,13] (Figure 2b). This double-ITCZ pattern is featured with two narrow bands of ITCZ. Except for a perennial northern ITCZ, a weak ITCZ also appears in the southern hemisphere. Considering such double ITCZs distinctively occur in March-April, the present study focuses on this season. 


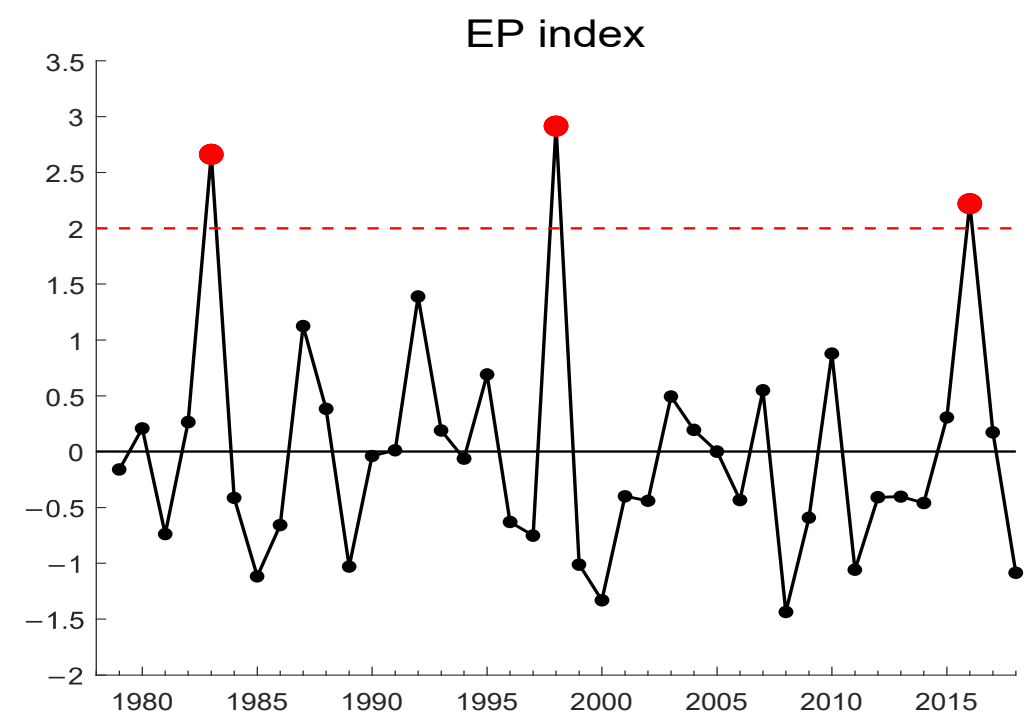

Figure 1. EP index (i.e., Niño-3 index) in January-February during 1979-2018. Red solid circles denote the decaying year of three extreme El Niño events: 1983, 1998, 2016.
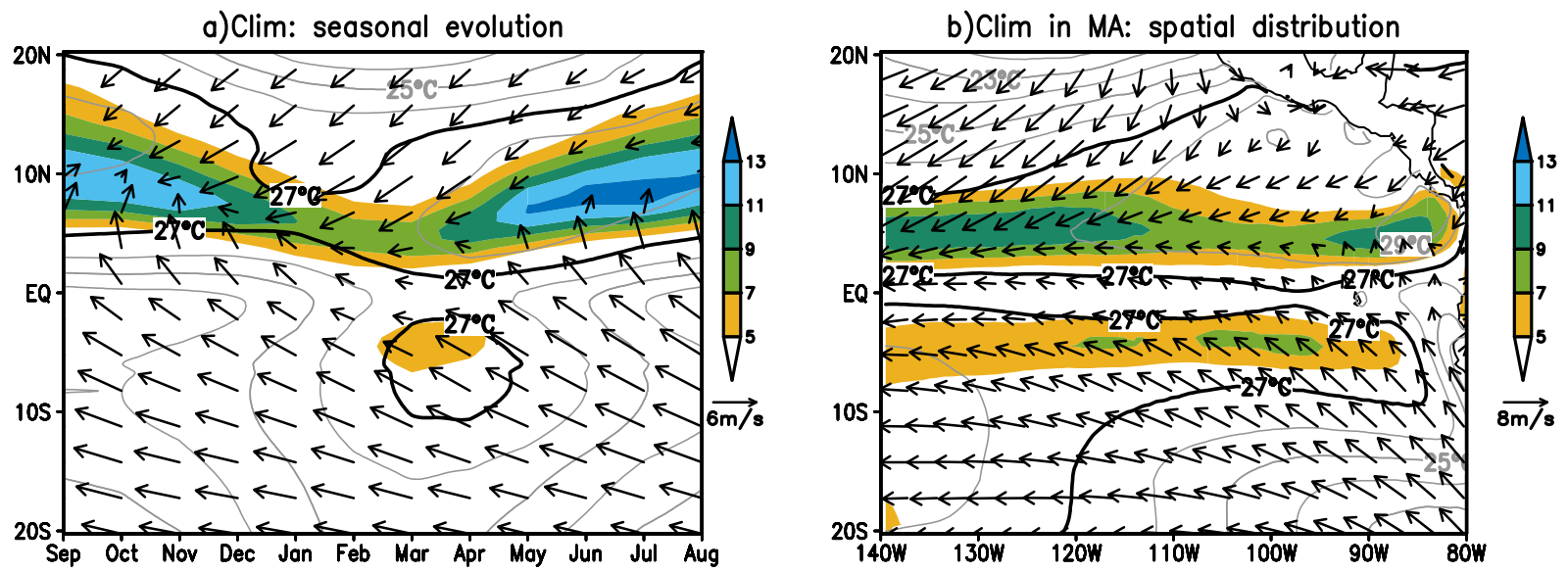

Figure 2. (a) Climatology: seasonal evolution of zonal-mean precipitation (color shaded; mm/day), SST (contours; ${ }^{\circ} \mathrm{C}$ ), and surface winds (vectors; $\mathrm{m} / \mathrm{s})$ over the eastern Pacific $\left(140^{\circ} \mathrm{W}-80^{\circ} \mathrm{W}\right) ;(\mathbf{b})$ Climatology in March-April: spatial pattern of the precipitation (color shaded; $\mathrm{mm} /$ day), $\mathrm{SST}$ (contours; ${ }^{\circ} \mathrm{C}$ ), and surface winds (vectors; $\mathrm{m} / \mathrm{s}$; wind speed smaller than 1 $\mathrm{m} / \mathrm{s}$ has been masked out) over the tropical eastern Pacific.

Previous studies showed that El Niño events can remarkably modulate the interannual variability of double ITCZs. In addition, different types of El Niño have a different impact on the double ITCZs [10,12-16]. For eastern Pacific-type (EP-type) El Niños [17,18], the northern and southern ITCZs both move to the equator, and double ITCZs change to be a broad equatorial ITCZ band. For central Pacific-type (CP-type) El Niños [19-21], the northern ITCZ is strengthened and the southern ITCZ is weakened.

This study aims to investigate and contrast how the three strongest EP-type El Niños modulate double ITCZs during the boreal spring. We found that the regulations of the 1982/1983 and 1997/1998 El Niños on double ITCZs were in line with the influence of typical EP-type El Niños. Whereas the 2015/2016 event's regulation was unique with a strengthened southern ITCZ. Different meridional SST anomaly patterns can account for these differences. During the boreal spring of 1983 and 1998, there was a meridionally symmetric structure of SST warming with a maximum at the equator. In contrast, during the boreal spring of 2016, SST warming maximum emerged off the equator. 
This paper is organized as follows. Section 2 provides materials and methods. Section 3 investigates the modulation processes of three strong El Niños on double ITCZs. The discussion and conclusions are given in Section 4.

\section{Materials and Methods}

In this study, the data were provided by the European Centre for Medium-Range Weather Forecasts (ECMWF) interim reanalysis (ERA-Interim) dataset [22,23]. We analyzed the monthly mean SST, precipitation, and winds at $10 \mathrm{~m}$ (referred to as surface winds), with a horizontal resolution of $0.75^{\circ} \times 0.75^{\circ}$ from January 1979 to December 2018 . We also used the $2.5^{\circ} \times 2.5^{\circ}$ monthly data from the Climate Prediction Center (CPC) Merged Analysis of Precipitation (CMAP) [24]. The results analyzed using the CMAP were consistent with those based on the ERA-Interim. Considering ERA-Interim data has a high resolution, this study primarily documented the results based on the ERA-Interim dataset. The climatology period in this study was 1979-2018.

The ITCZ was identified using the monthly-mean rainfall exceeding $5 \mathrm{~mm} /$ day $[10,13]$. The location of the ITCZ was represented by the latitude of the maximal zonal-mean precipitation $[16,25,26]$. We measured the intensity of the ITCZ by the magnitude of the zonal-mean precipitation.

To select the extreme El Niño events, we calculated the Niño-3 index [18] in JanuaryFebruary (JF) from 1979-2018. If the Niño-3 SST value of a year exceeded 2 standard deviations, the year was defined as the decaying year of an extreme El Niño event. According to this standard, there were three extreme El Niño events during 1979-2018, including the events of 1982/1983, 1997/1998, and 2015/2016 (Figure 1). In addition, all three events can be recognized as EP-type El Niños based on the Niño-3 index. We used the Niño-3 index (averaged SSTA over the region $\left(150^{\circ} \mathrm{W}-90^{\circ} \mathrm{W}, 5^{\circ} \mathrm{S}-5^{\circ} \mathrm{N}\right)$ ) as the EP index. We also calculated the El Niño Modoki index (EMI) [19] in January-February (JF) from 1979-2018 (not shown). We used EMI as the CP index, and the EMI is defined as follows:

$$
\mathrm{EMI}=(\mathrm{SSTA})_{\mathrm{A}}-0.5 \times(\mathrm{SSTA})_{\mathrm{B}}-0.5 \times(\mathrm{SSTA})_{\mathrm{C}}
$$

The brackets in the above equation denote the averaged SSTA over each of the regions A $\left(165^{\circ} \mathrm{E}-140^{\circ} \mathrm{W}, 10^{\circ} \mathrm{S}-10^{\circ} \mathrm{N}\right), \mathrm{B}\left(110^{\circ} \mathrm{W}-70^{\circ} \mathrm{W}, 15^{\circ} \mathrm{S}-5^{\circ} \mathrm{N}\right)$, and $\mathrm{C}\left(125^{\circ} \mathrm{E}-145^{\circ} \mathrm{E}\right.$, $\left.10^{\circ} \mathrm{S}-20^{\circ} \mathrm{N}\right)$. Based on the standard deviation of EP index and CP index, these three events were all EP-type El Niños.

\section{Results}

\subsection{Climatology of Double ITCZs}

A strong and distinctive seasonal evolution for precipitation can be observed in the eastern Pacific Ocean (Figure 2a). A single belt of ITCZ generally locates in the northern hemisphere $(\mathrm{NH})$. Its position fluctuated in the north-south direction with the seasons, reaching the southernmost point in boreal spring and the northernmost point in boreal autumn. In particular, besides this long-standing northern ITCZ band, an ITCZ also appeared in the southern hemisphere (SH) during boreal spring (March-April) $[10,13,27]$ (Figure 2a). The ITCZ belt was collocated with both the warmest SST and strong convergence.

For the climatology of March-April, a unique double-ITCZ pattern appeared over the eastern Pacific Ocean. The spatial pattern of double-ITCZ is shown in Figure $2 b$. Two zonally elongated precipitation bands were located straddling the equator, confined to the region where SST was warmer than $27^{\circ} \mathrm{C}$. In addition, northeasterly winds and cross-equatorial southeasterly winds converged in the northern ITCZ.

\subsection{Impacts of the Three Extreme El Niños}

\subsubsection{Seasonal Evolution}

For the 1982/1983 El Niño, warm SSTs (larger than $27^{\circ} \mathrm{C}$ ) at the equator persisted from November 1982 to June 1983, and these warm SSTs replaced the climatic cold tongue. Accompanying the disappearance of the cold tongue during March-April, the northern 
ITCZ and southern ITCZ migrated to each other. Over the eastern Pacific Ocean, the climatic double-ITCZ pattern was replaced by an individual broad ITCZ band at the equator during the boreal spring of 1983 (Figure 3a).
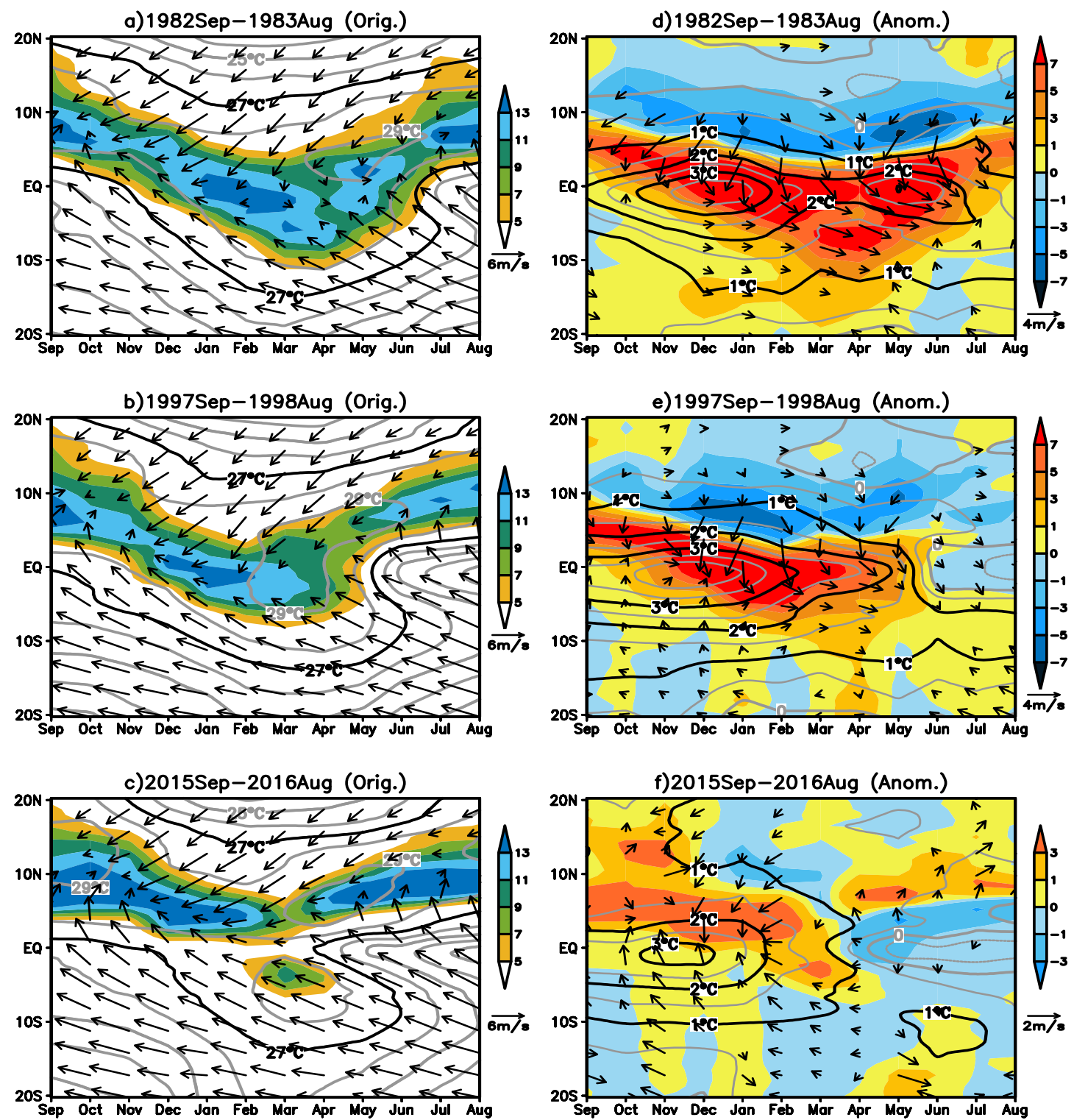

Figure 3. Left panels: Seasonal evolution of original zonal-mean precipitation (color shaded; mm/day), SST (contours; ${ }^{\circ} \mathrm{C}$ ), and surface winds (vectors; m/s; wind speed smaller than $1 \mathrm{~m} / \mathrm{s}$ has been masked out) over the eastern Pacific (140 W-80 W) for three extreme events: (a) 1982/1983, (b) 1997/1998, and (c) 2015/2016. Right panels: (d) 1982/1983, (e) $1997 / 1998$, and (f) 2015/2016, i.e., seasonal evolution of zonal-mean precipitation, SST, and surface winds, but for their anomalies.

The impact of the 1997/1998 El Niño event on precipitation bands over the eastern Pacific Ocean was similar to that of the 1982/1983 El Niño event. For 1997/1998 El Niño, the climatic double-ITCZ pattern also changed to be a broad equatorial ITCZ belt during the boreal spring of the decaying year (Figure $3 b$ ).

The impact of 2015/2016 El Niño on ITCZs (Figure 3c) was different from that of $1982 / 1983$ and $1997 / 1998$ El Niños. The warm SSTs (larger than $27^{\circ} \mathrm{C}$ ) at the equator only lasted until March 2016. In March-April of 2016, the cold tongue disappeared, but the SST at the equator was lower than the SST on both sides of the equator. In addition, two belts of ITCZs also emerged in March-April of 2016. Such a double-ITCZ structure was similar 
to the climatic state, except for a strengthened southern ITCZ. This feature was neither like the influence of a typical EP-type event nor was it like a typical CP-type event.

We also examined the seasonal evolution for anomalies. Results showed that for the 1982/1983 and 1997/1998 events (Figure 3d,e), the equatorial precipitation significantly increased in March-April, and such enhancement in equatorial precipitation could be traced back to November of the El Niño's developing year. While for the 2015/2016 event (Figure 3f), the precipitation strengthened in March-April mainly emerged in the southern ITCZ. Overall, in comparison to the earlier two extreme El Niños, 2015/2016 El Niño exhibited different impacts on the seasonal evolution of ITCZs (Figure 3).

\subsubsection{Meridional Structure of SSTs and ITCZs in March-April}

We examined the zonally averaged precipitation in climatology and the three strongest events in March-April (Figure 4a). For climatology, two precipitation maximum bands were situated in both the northern and southern hemispheres, accompanied by a minimum at the equator. For the 1982/1983 and 1997/1998 events, these two precipitation maximum bands were moving towards each other to merge as one intense equator ITCZ. The spring rainfall at the equator significantly increased in 1983 and 1998. Different from the impact of the former 1982/1983 and 1997/1998 events, there was still a double ITCZ pattern in 2016. The latitudes of the two precipitation maxima remained almost the same as climatology, and the intensity of southern ITCZ strengthened. Satellite data illustrated that there were five daily states of ITCZ, such as northern ITCZ, southern ITCZ, equator ITCZ, double ITCZ, and absent ITCZ [28,29]. In March-April of 1983 and 1998, the El Niño events modulated the ITCZ position to form an equator ITCZ type. In 2016, the El Niño event modulated the intensity of the ITCZs to form a symmetrical double ITCZ with the same intensity in the southern ITCZ and the northern ITCZ. This double ITCZ was different from the climatic north-dominant and south-secondary double ITCZ.
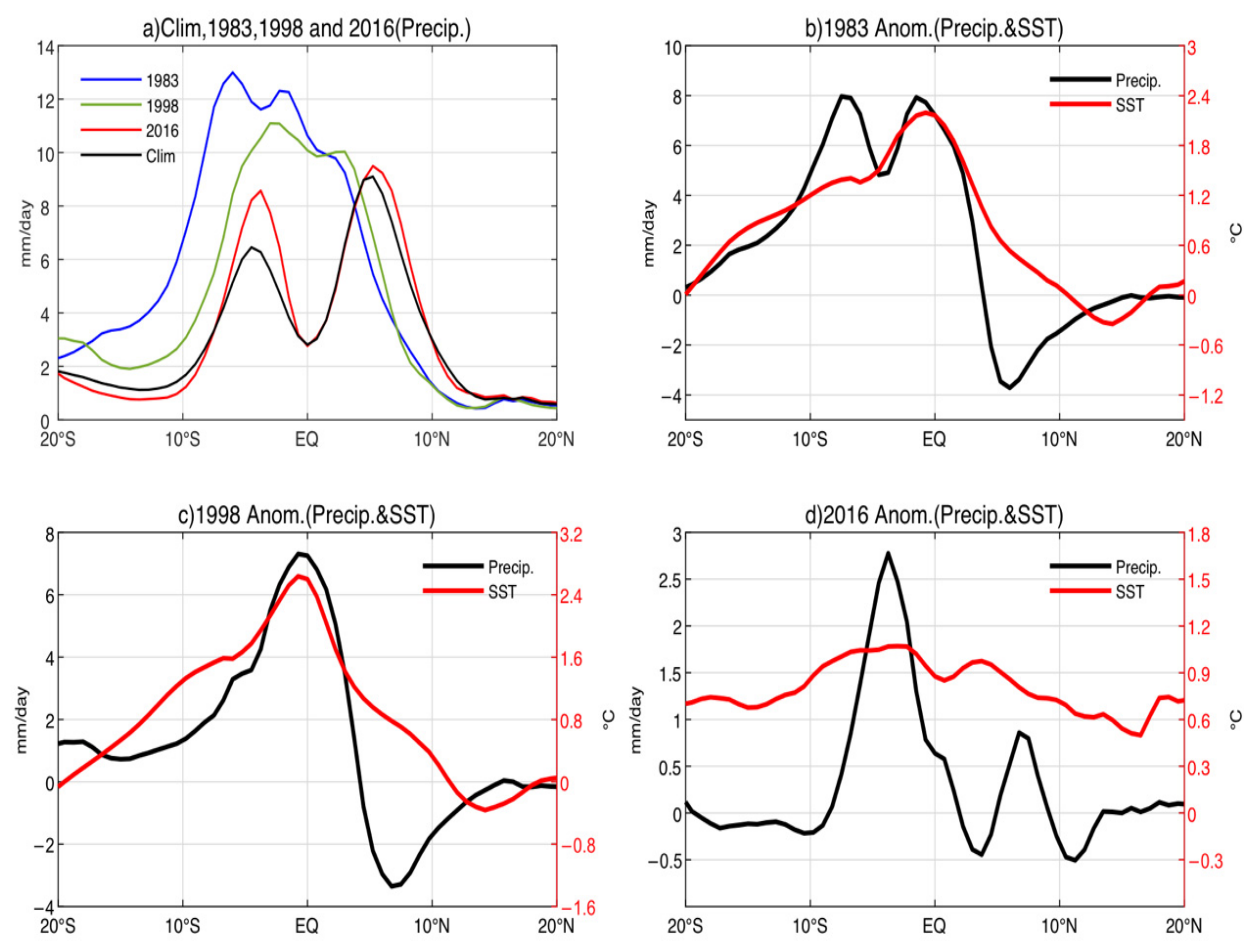

Figure 4. (a) Zonal-mean precipitation (mm/day) over the eastern Pacific $\left(140^{\circ} \mathrm{W}-80^{\circ} \mathrm{W}\right)$ in March-April for climatology (black), 1983 (blue), 1998 (green) and 2016 (red). Anomalous zonal-mean precipitation (black; mm/day) and SST (red; ${ }^{\circ} \mathrm{C}$ ) between $140^{\circ} \mathrm{W}-80^{\circ} \mathrm{W}$ for three extreme El Niños in March-April: (b) 1983 (c) 1998, (d) 2016.

For the 1982/1983 and 1997/1998 El Niños, SST increased covering latitudes approximately from $10^{\circ} \mathrm{N}$ to $20^{\circ} \mathrm{S}$. Although the SST warming occurred in a broad range, 
the maximum SST warming (approximately $2{ }^{\circ} \mathrm{C}$ ) emerged right over the equator. Regarding that deep convections typically located on the warmest ocean $[10,13,25,26,30-32]$, two ITCZs moved to the equator. Such approaching migrations of two ITCZs led to a dramatic enhancement of precipitation at the equator during March-April in 1983 and 1998 (Figure $4 \mathrm{~b}, \mathrm{c}$ ). A SST warming of about $2.5^{\circ} \mathrm{C}$ corresponds to a precipitation growth of about $8 \mathrm{~mm}$ /day (Figure $4 \mathrm{~b}, \mathrm{c}$ ).

Unlike the two previous strong El Niños, the anomalous zonal-mean SST pattern exhibited two maxima on both sides of the equator and a minimum at the equator for the 2015/2016 El Niño (Figure 4d). Such a meridional SST warming structure could not change the positions of the two ITCZs; it changed the intensity of two ITCZs, especially the southern ITCZ. The SST warming in the SH (approximately $1{ }^{\circ} \mathrm{C}$ ) enhanced the precipitation in the southern ITCZ by about $2.7 \mathrm{~mm} /$ day (Figure $4 \mathrm{~d}$ ). In addition, the latitude of the minimum (or maximum) of anomalous precipitation was not perfectly in compliance with the latitude of the minimum (or maximum) of anomalous SST. This was because the anomalous precipitation depended on not only the anomalous SST but also the climatic SST and precipitation.

Surface momentum balances [30] and the 'energy-flux' framework [25,26,32] may account for the relation of the ITCZs with SST. Especially in the energy-flux framework, the strengthened equatorial ITCZ (or the strengthened southern ITCZ) could be explained by enhanced atmospheric net energy input, associated with increased equatorial (or southern) SST for 1982/1983 and 1997/1998 (or 2015/2016) extreme El Niños shown in Figure 4b,c (or Figure 4d).

\subsubsection{Spatial Distributions in March-April}

During boreal spring in 1983 and 1998, zonally the SST warming larger than $1{ }^{\circ} \mathrm{C}$ could cover the entire tropical eastern Pacific Ocean from $140^{\circ} \mathrm{W}$ to $80^{\circ} \mathrm{W}$ (Figure 5a,b). During boreal spring in 2016, the warming range greater than $1^{\circ} \mathrm{C}$ only extended from $140^{\circ} \mathrm{W}$ to $100^{\circ} \mathrm{W}$ (Figure 5c). Off the West Coast of South America, the SST anomalies in 1983 and 1998 could reach more than $3{ }^{\circ} \mathrm{C}$, while the SST anomalies in 2016 could be lower than $0.5^{\circ} \mathrm{C}$.

For the 1982/1983 and 1997/1998 El Niños, meridionally the SST warming was the strongest at the equator $\left(3^{\circ} \mathrm{S}\right.$ to $\left.3^{\circ} \mathrm{N}\right)$ in March-April of the decaying year (Figure $5 \mathrm{a}, \mathrm{b}$ ). With the strongest increase of SST, convergence anomalies also appeared at the equator. The two ITCZs both moved toward the equator. Such equatorward movements of the double ITCZs strengthened the equatorial precipitation remarkably over the entire tropical eastern Pacific Ocean. While for the 2015/2016 El Niño, west of $100^{\circ} \mathrm{W}$, SST warming maxima $\left(>1.25^{\circ} \mathrm{C}\right)$ emerged in both southern and northern hemisphere in March-April of the decaying year (Figure 5c). With the relative higher SST off the equator, convergence anomalies also emerged off the equator. The influence of the anomalous SST on the anomalous precipitation appeared to increase the precipitation at the climatic ITCZ latitudes, especially the precipitation in the southern ITCZ (Figure 5c). 


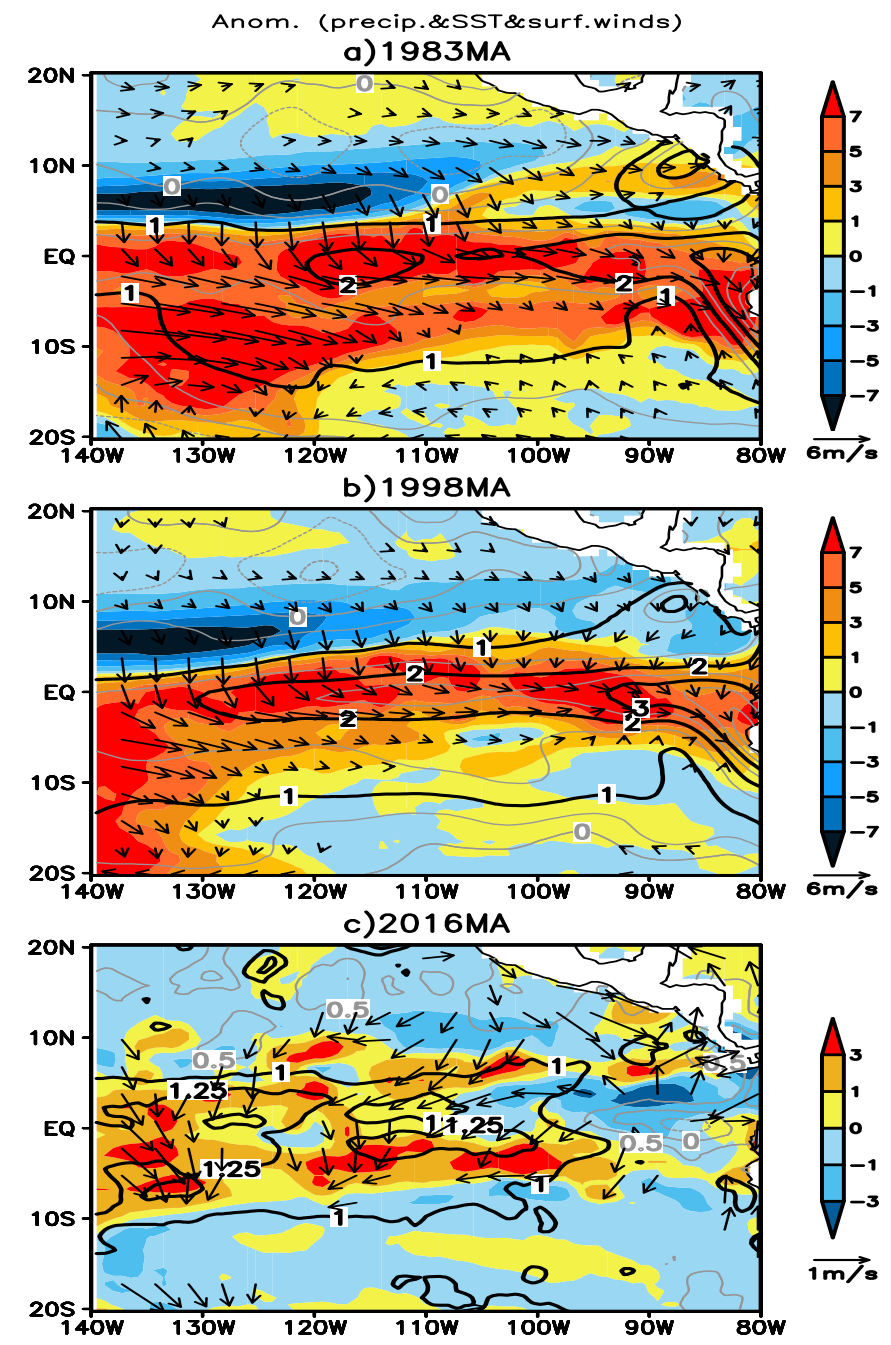

Figure 5. Spatial pattern of the anomalies of precipitation (color shaded; mm/day), SST (contours; ${ }^{\circ} \mathrm{C}$ ), and surface winds (vectors; $\mathrm{m} / \mathrm{s}$; wind speed smaller than $0.5 \mathrm{~m} / \mathrm{s}$ has been masked out) over the tropical eastern Pacific $\left(140^{\circ} \mathrm{W}-80^{\circ} \mathrm{W}, 20^{\circ} \mathrm{S}-20^{\circ} \mathrm{N}\right)$ in March-April for (a) 1983, (b) 1998 and (c) 2016 .

\subsection{Modulation of Meridional Delta SST on Double ITCZs}

3.3.1. Relationship between SST and Double ITCZs in 1982/1983, 1997/1998, and 2015/2016 Events

As mentioned above in Section 3.2, the meridional structure of SST was tightly coupled to the position and strength of the ITCZs. To quantify the influence of SST meridional structure on ITCZ, we calculated the meridional delta SST. A large delta SST represents high SST anomalies at the equator and relative lower SST anomalies at the north and south sides of the equator. We analyzed the relation between the EP index and delta SST, delta SST, and distance of the two ITCZs, delta SST and precipitation.

In Figure 6, EP (or CP) represents EP-type (or CP-type) El Niño. SSTA $\mathrm{EQ}$ (or SSTA $\mathrm{NH}_{\mathrm{H}}$

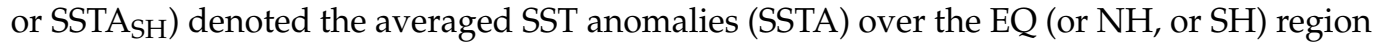
and $\mathrm{PA}_{\mathrm{EQ}}$ (or $\mathrm{PA}_{\mathrm{NH}}$ or $\mathrm{PA}_{\mathrm{SH}}$ ) denoted the average precipitation anomalies (PA) over the $\mathrm{EQ}$ (or $\mathrm{NH}$, or $\mathrm{SH})$ region. Here, $\mathrm{EQ}$ (or $\mathrm{NH}$, or $\mathrm{SH})$ was the region within $\left(140^{\circ} \mathrm{W}-80^{\circ} \mathrm{W}\right.$, $\left.1.5^{\circ} \mathrm{S}-1.5^{\circ} \mathrm{N}\right)$, or $\left(140^{\circ} \mathrm{W}-80^{\circ} \mathrm{W}, 3.75^{\circ} \mathrm{N}-6.75^{\circ} \mathrm{N}\right)$, or $\left(140^{\circ} \mathrm{W}-80^{\circ} \mathrm{W}, 3^{\circ} \mathrm{S}-6^{\circ} \mathrm{S}\right)$. 
a) EP index vs. delta SST

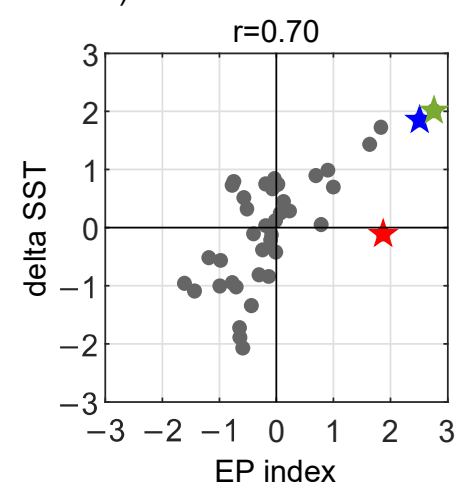

b) delta SST vs. Dis.Pre.Max

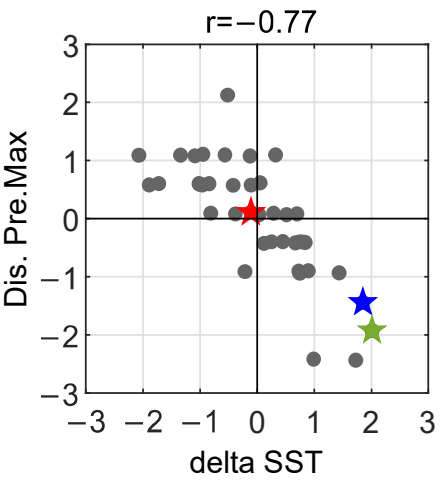

c) delta SST vs. EQ Pre.

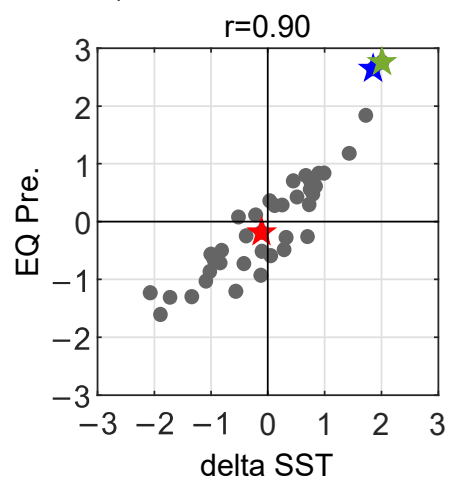

Figure 6. Scatter diagrams of (a) EP index (i.e., Niño 3 index) versus delta SST (i.e., $\mathrm{SSTA}_{\mathrm{EQ}}-0.5^{*}\left(\mathrm{SSTA}_{\mathrm{SH}}+\mathrm{SSTA}_{\mathrm{NH}}\right)$ ); (b) delta SST versus change in distance between two ITCZs (i.e., anomalies for $\mid$ Lat $_{\text {precip.max.NH }}-$ Lat $_{\text {precip.max.SH }} \mid$ ); (c) delta SST versus equatorial precipitation for $\mathrm{EP}$ (i.e., $\mathrm{PA}_{\mathrm{EQ}}-0.5^{*}\left(\mathrm{PA}_{\mathrm{SH}}+\mathrm{PA} \mathrm{NH}_{\mathrm{H}}\right)$ ). For each subfigure, solid stars denote the extreme El Niño decaying years: 1983 (blue), 1998 (green), and 2016 (red). All these indices are calculated for the season March-April and are normalized. In all subfigures, the correlations are statistically significant at a $99 \%$ confidence level.

During 1979-2018, EP index and delta SST were highly correlated (Figure 6a). In most cases, the delta SST covaried with the EP index. This was well reflected in the strong $1982 / 1983$ and $1997 / 1998$ events. When the equatorial SST was warming, the delta SST was also high (blue star and green star in Figure 6a). While the 2015/2016 strong event was unique: when the equatorial SST was warming, the delta SST was close to zero (red star in Figure 6a).

The delta SST is the factor that modulates the position and intensity of double ITCZs. The impacts of three extreme events on the position of ITCZ were different (Figure 6b). In the $1982 / 1983$ and 1997/1998 events, the delta SST was positive and large, representing a symmetric SST warming with a maximum at the equator. Such meridional SST structure drives the north and south ITCZ to move toward each other, reducing the distance between the south and north ITCZ (blue star and green star in Figure 6b). In the 2015/2016 event, the delta SST was close to zero, and the north and south ITCZ remained almost stationary in their original positions (red star in Figure 6b).

The impacts of three extreme events on the intensity of precipitation were also different (Figure 6c). In line with the typical EP-type event, for the 1982/1983 and 1997/1998 events, a positive and large delta SST (i.e., a relative higher equatorial SST warming) driven the northern and southern ITCZ shift toward the equator, which significantly increased the equatorial precipitation and reduced the precipitation off the equator over the eastern Pacific Ocean. For the 2015/2016 event, a negative and small delta SST (i.e., cooling or a relative lower equatorial SST warming) was linked with a decrease of rainfall at the equator and an increase of rainfall off the equator.

\subsubsection{Time Evolution of Delta SST over the Eastern Pacific Ocean}

The time evolution of delta SST is shown in Figure 7 for three strong events. In the 1982/1983 El Niño event, the positive delta SST could last until June 1983. In MarchApril of 1983, a positive delta SST appeared over the entire eastern Pacific Ocean, with an intensity ranging from 1 to 1.5. In the 1997/1998 El Niño event, the positive delta SST could last until May 1998. In March-April of 1998, a positive delta SST appeared over the entire eastern Pacific, with an intensity ranging from 0.5 to 1.5. In the 2015/2016 El Niño event, the positive delta SST could only last until March 2016. Boreal spring of 2016 (March-April) was the transition period for delta SST from positive to negative. 

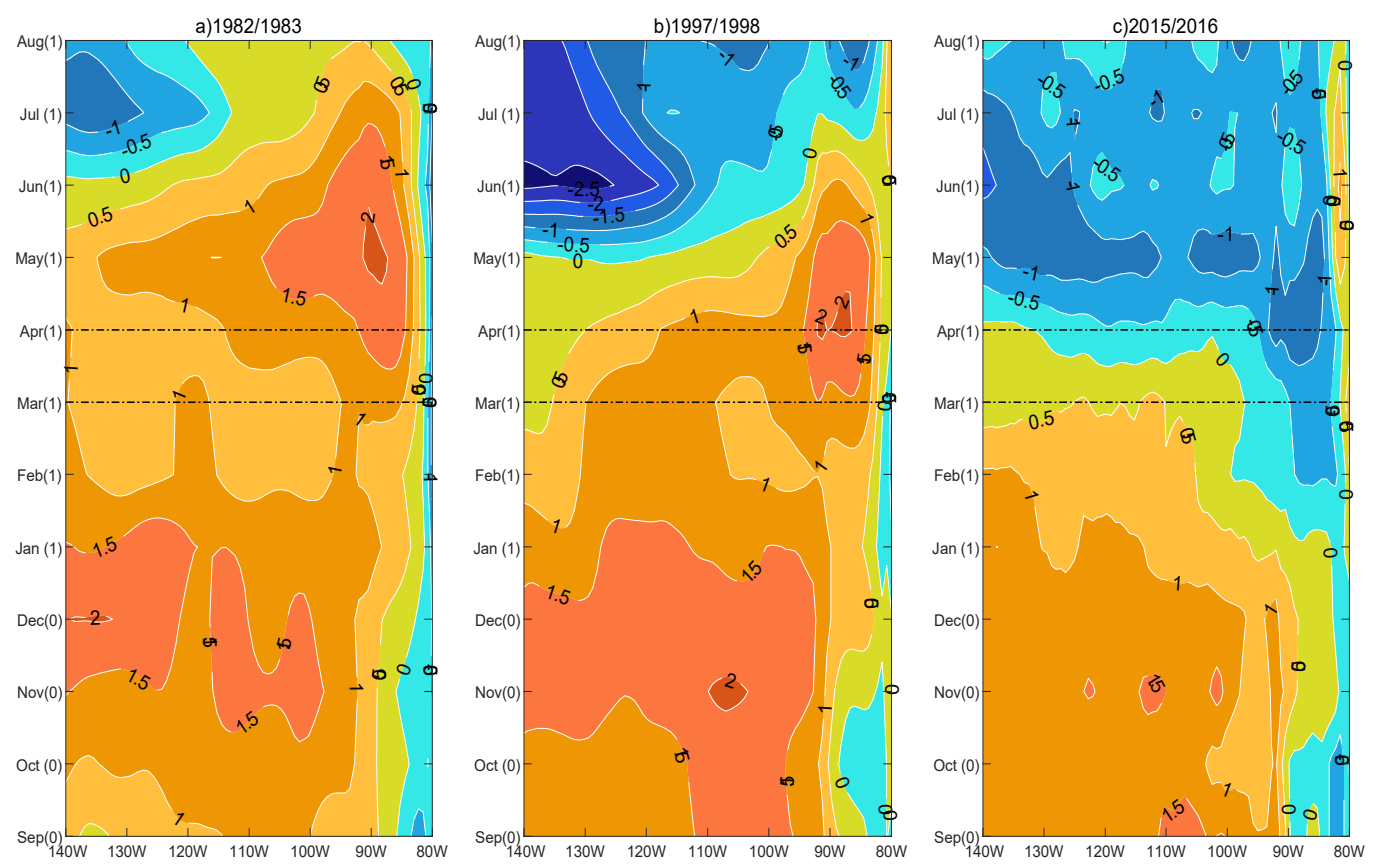

Figure 7. Time evolution of the delta SST over the eastern Pacific during the three strongest El Niño years: (a) 1982/1983, (b) $1997 / 1998$, (c) $2015 / 2016$. The delta SST represents $\mathrm{SSTA}_{\mathrm{EQ}}-0.5^{*}\left(\mathrm{SSTA}_{\mathrm{SH}}+\mathrm{SSTA}_{\mathrm{NH}}\right)$. Here EQ (or NH, or SH) denotes the latitudes within $\left(1.5^{\circ} \mathrm{S}-1.5^{\circ} \mathrm{N}\right)\left(\right.$ or $\left(3.75^{\circ} \mathrm{N}-6.75^{\circ} \mathrm{N}\right)$, or $\left(3^{\circ} \mathrm{S}-6^{\circ} \mathrm{S}\right)$ ). The numbers in parentheses following the months are 0 for the developing year and 1 for the decaying year of El Niño.

In other words, during the spring of 1983 and 1998, SST anomalies were relatively warm at the equator and relatively cold off the equator over the eastern Pacific Ocean, which favored an increase of equatorial precipitation. Whereas during the spring of 2016, SST anomalies were relatively cold at the equator and relatively warm off the equator, which favored an increase of precipitation off the equator. In particular, the largest increase in precipitation emerged in the southern ITCZ, where the SST increased the most.

\subsubsection{Possible Explanation}

In the peak period (i.e., November-December, ND), the values of EP index of 1982/1983, $1997 / 1998$ and $2015 / 2016$ all exceeded $2.5^{\circ} \mathrm{C}$. The three strongest events had comparable magnitude, except for a slightly weaker amplitude in 2015/2016 events. EP index (Figure 8a) and CP index (Figure 8b) indicate that the 1982/1983 and 1997/1998 events can be recognized as pure EP-type events, while 2015/2016 event also has characteristics of a CP-type event.

The above classification are also valid for the March-April period of the El Niño decaying year. Although the EP index had dropped rapidly, it was still much greater than the CP index for three strongest events. In March-April of 1983, the EP index was above $1.5^{\circ} \mathrm{C}$ (Figure 8a), while the $\mathrm{CP}$ index was negative (Figure 8b). The situation in 1998 was similar to that in 1983. These two events have only the characteristics of EP-type El Niños. There were positive SST anomalies in the eastern Pacific, including the equatorial far east Pacific Ocean (see also Figure 5a,b). At the same time, the 1982/1983 and 1997/1998 events have a better persistence. In March-April of 1983 and 1998, the zonal-mean delta SST remained a large positive value (Figure $8 \mathrm{c}$ ). 

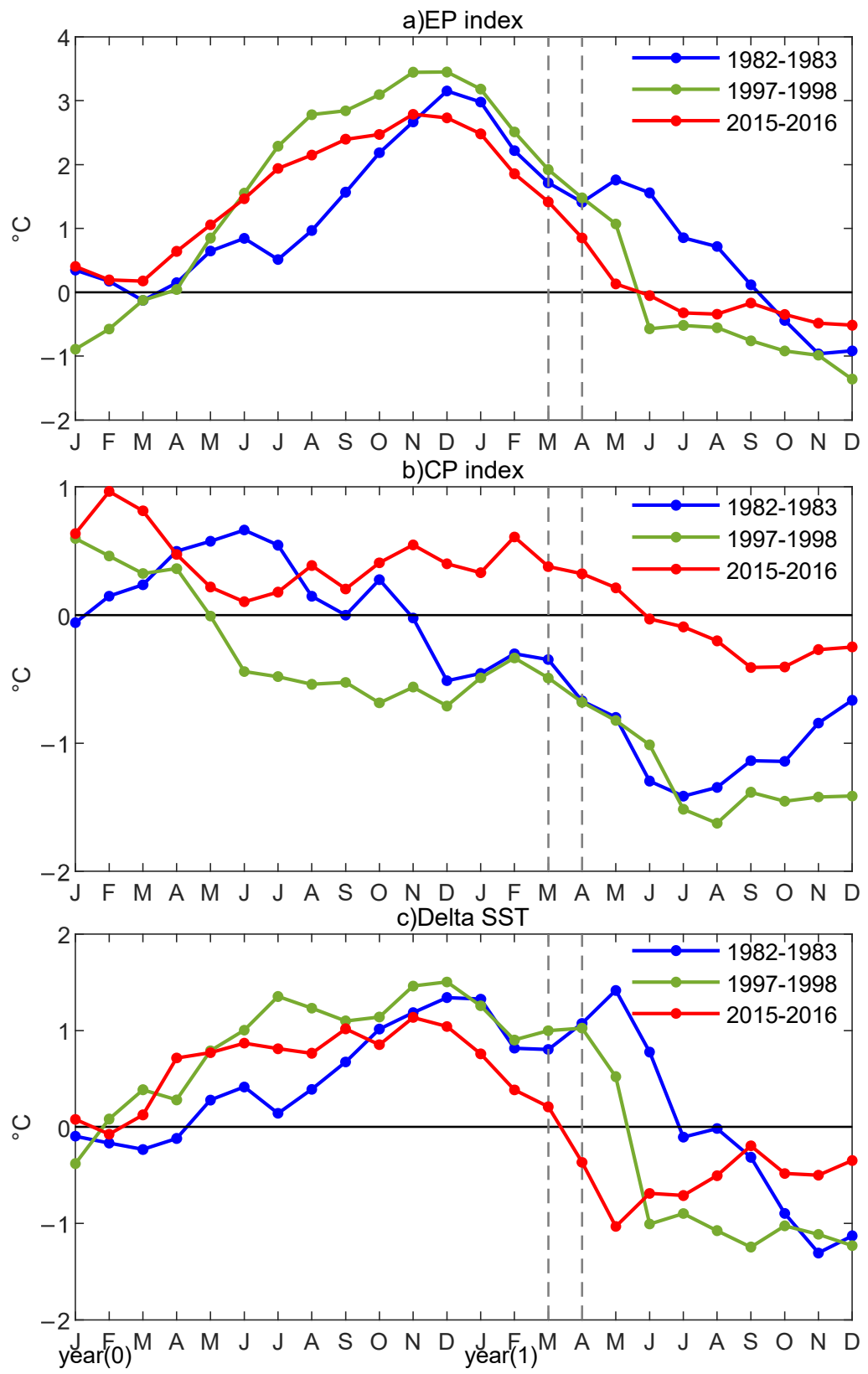

Figure 8. Time evolution of three indices: (a) EP index; (b) CP index and (c) zonal-mean delta SST. For each subfigure, 1982/1983 event (blue), 1997/1998 event (green), 2015/2016 event (red).

The 2015/2016 El Niño is different. The value of the CP index in March-April of 2016 was positive, and the intensity was about $0.5{ }^{\circ} \mathrm{C}$ (Figure 8b). The $2015 / 2016$ event also had the characteristics of a CP-type El Niño. There were negative SST anomalies in the equatorial far eastern Pacific Ocean (see also Figure $5 c$ ). At the same time, compared with the two previous extreme El Niños, the 2015/2016 El Niño decayed faster (e.g., the SST in Niño 3 region). Accompanying the rapid decline of the 2015/2016 event, its SST maximum was no longer at the equator, but at the latitude off the equator. Specifically, west of $90^{\circ}$ $\mathrm{W}$, there was a relative lower equatorial SST warming; east of $90^{\circ} \mathrm{W}$, there was cooling at the equator. In March-April of 2016, the zonal-mean delta SST switched from positive to negative (Figure 8c).

\section{Discussion and Conclusions}

In this study, we examined the modulating process of the three strongest El Niños on the double ITCZs. Our results indicate that the impact of 2015/2016 El Niño on the 
position and intensity of double ITCZs is completely different from that of 1982/1983 and 1997/1998 El Niños. The 1982/1983 and 1997/1998 El Niños could drive both northern and southern ITCZs to migrate toward the equator to form a broad and intense equatorial ITCZ. In contrast, the 2015/2016 El Niño did not change the latitudes of double ITCZs, it strengthened the precipitation in double ITCZs, especially the southern ITCZ.

These different regulations can be attributed to the different meridional structures of SSTs represented by the delta SST. During the boreal spring of 1983 and 1998, there was a meridionally symmetric structure of SST warming with a maximum at the equator. In contrast, during the boreal spring of 2016, there was a meridionally symmetric structure of SST warming with two maxima on both sides of the equator and a minimum at the equator.

This article and the published article [16] focus on different aspects of El Niño's impact on ITCZ. The published results [16] emphasized the general characteristics of multiple EP-type events, and the general characteristics of multiple CP-type events, respectively. In a previous study, we compared the different variability of double ITCZ structure between EP-type El Niños and CP-type El Niños. The previous study [16] highlighted that the typical EP-type events move the northern and southern ITCZ to the equator and enhanced equatorial precipitation. The typical CP-type events induce a strengthened northern ITCZ and a weakened southern ITCZ.

While our present results highlight the internal diversity within EP-type events. The three extreme events are all EP-type events. The regulation of 1982/1983 and 1997/1998 El Niños on the double ITCZs were in line with typical EP-type El Niños. Although the 2015/2016 El Niño event is one of the strongest EP-type El Niños, its regulation on double ITCZ is completely different from typical EP-type El Niño. The 2015/2016 El Niño strengthened both the southern ITCZ and northern ITCZ, particularly the southern ITCZ. The value of the EP index for the 2015/2016 event is not weak. The meridional structure of SST is the factor that modulates the ITCZs, rather than the EP index. The meridional SST structure of the 2015/2016 event is different from that of most EP-type events. This is probably because the 2015/2016 El Niño declined relatively faster, and it has some characteristics of a CP-type El Niño.

It is interesting to note that although the 2015/2016 event is an EP-type event, and has the characteristics of a CP-type event; its impact on ITCZ is neither like a typical EP-type event nor a typical CP-type event. This can be explained as follows. Albeit the EP index in March-April of 2016 was high, for the SST meridional structure, the SST anomalies off the equator were higher than the equatorial SST anomalies. Therefore, unlike a typical EP-type event, the 2015/2016 event cannot excite a strong convergence towards the equator. Although the 2015/2016 event has the characteristics of a CP-type event, at the equator, the negative SST anomalies are mainly confined to the far eastern Pacific (specifically, west of $90^{\circ} \mathrm{W}$ ), positive SST anomalies emerged east of $90^{\circ} \mathrm{W}$. The $2015 / 2016$ event did not induce a north-warm and south-cool SSTA pattern. Therefore, unlike a typical CP-type event, the 2015/2016 event cannot induce C-shaped wind anomalies that converge towards the northern ITCZ. In fact, during the boreal spring of 2016, the wind anomalies converged towards the southern ITCZ.

Recent research reported that different Quasi-Biennial Oscillation (QBO) have different impacts on the deep convection and precipitation of ITCZ [33]. Generally, the deep convection and precipitation tend to increase under QBO easterly conditions, while the deep convection and precipitation tend to decrease under QBO westerly conditions [33-35]. A westerly QBO phase was abruptly disrupted well before the completion of an easterly phase in January 2016 [36-40]. In March-April of 2016 (QBO easterly phase), accompanying the increased deep convection, precipitation in the northern and southern ITCZ also increased. This abrupt QBO disruption in 2016 may be linked to global warming and recently observed weakening of the QBO amplitude [36,41].

This study investigates the interannual variability of double ITCZs regulated by diverse EP-type events under varying climatic conditions. Global warming is not only reflected in the global mean surface temperature (GMST), but also in the equatorial sea 
surface temperature [42-44] For example, during 2000-2018, the SSTA trend in the equatorial eastern Pacific Ocean reached approximately $1{ }^{\circ} \mathrm{C}$ (Figure 9), implying the changing background SST. An El Niño-like state $[45,46]$ will appear in the tropical Pacific. Under this basic state, El Niño's diversity is more prominent. Various studies have shown that CP-type events have increased after 2000 [47,48]. In 2014-2016, there were consecutive CP-type event in 2014/15 and EP-type event in 2015/2016 [6,44]. Among them, the 2015/2016 extreme EP-type event showed different characteristics and climate impacts from the two previous extreme El Niño events (i.e., the 1982/1983 and 1997/1998 events), such as the impacts on double ITCZs. It will be interesting to further study the relationship between ENSO diversity and ITCZs in the context of global warming, and related modulation processes in observations and simulations.

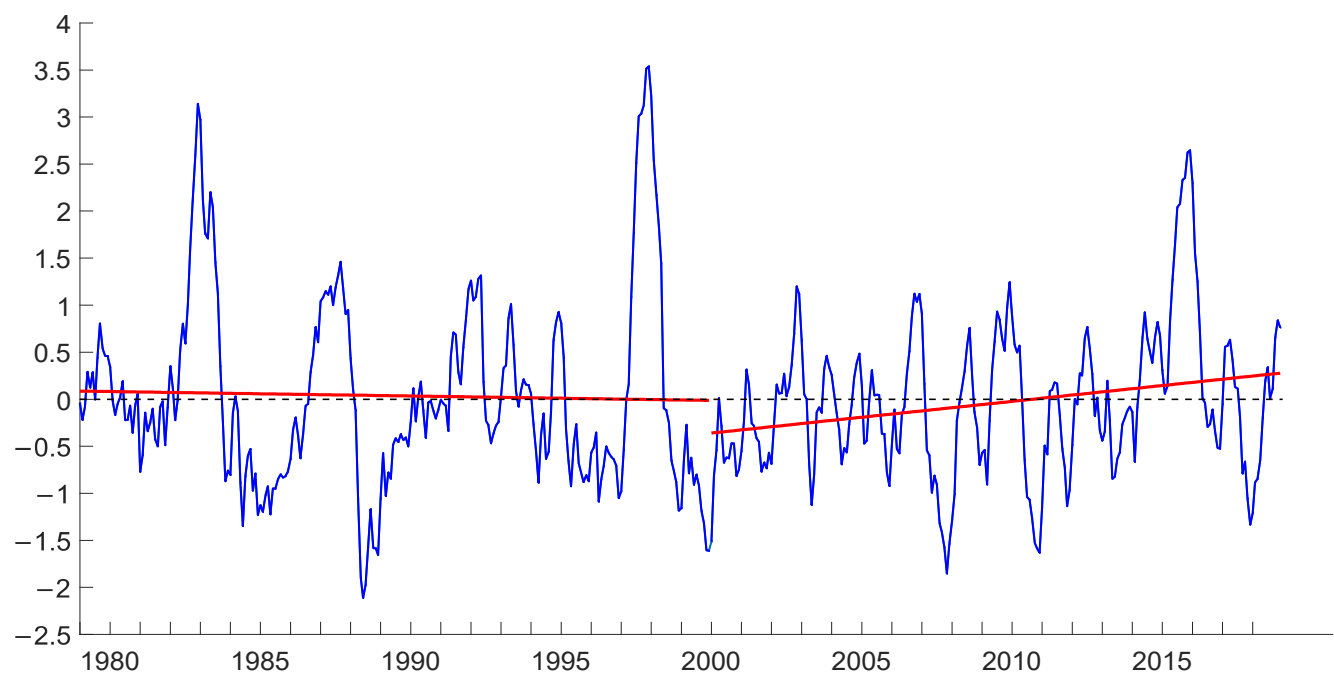

Figure 9. Equatorial SST averaged over the eastern Pacific Ocean $\left(140^{\circ} \mathrm{W}-80^{\circ} \mathrm{W}, 5^{\circ} \mathrm{S}-5^{\circ} \mathrm{N}\right)$ during $1979-2018$. Red lines denote the trend during the period 1979-1999 and the period 2000-2018.

Author Contributions: Conceptualization, L.Y. and G.L.; methodology, L.Y. and J.X; software, Y.C., J.L. and S.Z.; formal analysis, Y.C., L.Y., G.L. and J.X.; data curation, J.L. and S.Z.; writing-original draft preparation, Y.C. and L.Y.; writing-review and editing, L.Y., G.L.; visualization, Y.C.; funding acquisition, L.Y. All authors have read and agreed to the published version of the manuscript.

Funding: This research was jointly funded by the National Key R\&D Program of China (Grant 2018YFC1505902), the Strategic Priority Research Program of Chinese Academy of Sciences (XDA20060503) and program for scientific research start-up funds of Guangdong Ocean University (R19061 \& R18023).

Institutional Review Board Statement: Not applicable.

Informed Consent Statement: Not applicable.

Data Availability Statement: The SST and surface winds datasets of the European Centre for Medium-Range Weather Forecasts (ECMWF) interim reanalysis (ERA-Interim) were provided by http:/ / apps.ecmwf.int/datasets / data/interim-full-moda/levtype=sfc/, accessed on 17 October 2020. The precipitation dataset of ERA-Interim was downloaded from their Web site at http:/ / apps.ecmwf.int/datasets / data/interim-mdfa/levtype=sfc/, accessed on 17 October 2020. The precipitation data from Climate Prediction Center (CPC) Merged Analysis of Precipitation (CMAP) was downloaded from https:/ / www.esrl.noaa.gov/psd/data/gridded/data.cmap.html, accessed on 17 October 2020. The datasets used in this study are publicly available online.

Acknowledgments: The authors would like to thank the Editor and three anonymous reviewers for their insightful comments and suggestions.

Conflicts of Interest: The authors declare no conflict of interest. 


\section{References}

1. Ren, H.L.; Wang, R.; Zhai, P.; Ding, Y.; Lu, B. Upper-ocean dynamical features and prediction of the super El Niño in 2015/16: A comparison with the cases in 1982/83 and 1997/98. J. Meteorol. Res. 2017, 31, 278-294. [CrossRef]

2. Xue, Y.; Kumar, A. Evolution of the 2015/16 El Niño and historical perspective since 1979. Sci. China Earth Sci. 2017, 60, 1572-1588. [CrossRef]

3. Paek, H.; Yu, J.Y.; Qian, C. Why were the 2015/2016 and 1997/1998 extreme El Niños different? Geophys. Res. Lett. 2017, 44, 1848-1856. [CrossRef]

4. Abellán, E.; McGregor, S.; England, M.H.; Santoso, A. Distinctive role of ocean advection anomalies in the development of the extreme 2015-16 El Niño. Clim. Dyn. 2018, 51, 2191-2208. [CrossRef]

5. Hu, S.; Fedorov, A.V. The extreme El Niño of 2015-2016: The role of westerly and easterly wind bursts, and preconditioning by the failed 2014 event. Clim. Dyn. 2019, 52, 7339-7357. [CrossRef]

6. Xie, R.; Fang, X. The unusual 2014-2016 El Niño events: Dynamics, prediction and enlightenments. Sci. China Earth Sci. 2020, 63, 626-633. [CrossRef]

7. Lim, Y.K.; Kovach, R.M.; Pawson, S.; Vernieres, G. The 2015/16 El Niño Event in Context of the MERRA-2 Reanalysis: A Comparison of the Tropical Pacific with 1982/83 and 1997/98. J. Clim. 2017, 30, 4819-4842. [CrossRef]

8. Xie, R.; Yang, Y. Revisiting the latitude fluctuations of the eastern Pacific ITCZ during the central Pacific El Niño. Geophys. Res. Lett. 2014, 41, 7770-7776. [CrossRef]

9. Philander, S.G.H.; Gu, D.; Lambert, G.; Li, T.; Halpern, D.; Lau, N.C.; Pacanowski, R.C. Why the ITCZ is mostly north of the equator. J. Clim. 1996, 9, 2958-2972. [CrossRef]

10. Zhang, C. Double ITCZs. J. Geophys. Res. Atmos. 2001, 106, 11785-11792. [CrossRef]

11. Xie, S.P.; Philander, S.G.H. A coupled ocean-atmosphere model of relevance to the ITCZ in the eastern Pacific. Tellus A 1994, 46, 340-350. [CrossRef]

12. Lietzke, C.E.; Deser, C.; Vonder Haar, T.H. Evolutionary Structure of the Eastern Pacific Double ITCZ Based on Satellite Moisture Profile Retrievals. J. Clim. 2001, 14, 743-751. [CrossRef]

13. Gu, G.; Adler, R.F.; Sobel, A.H. The eastern Pacific ITCZ during the boreal spring. J. Atmos. Sci. 2005, 62, 1157-1174. [CrossRef]

14. Xie, S.P.; Peng, Q.; Kamae, Y.; Zheng, X.T.; Tokinaga, H.; Wang, D. Eastern Pacific ITCZ dipole and ENSO diversity. J. Clim. 2018, 31, 4449-4462. [CrossRef]

15. Zhu, J.; Liu, Y.; Xie, R.; Chang, H. A Comparative Analysis of the Impacts of Two Types of El Niño on the Central and Eastern Pacific ITCZ. Atmosphere 2018, 9, 266. [CrossRef]

16. Yan, L.; Li, G. Double intertropical convergence zones over the eastern Pacific Ocean: Contrasting impacts of the eastern Pacific-and central Pacific-type El Niños. Atmos. Sci. Lett. 2018, 19. [CrossRef]

17. Rasmusson, E.M.; Carpenter, T.H. Variations in Tropical Sea Surface Temperature and Surface Wind Fields Associated with the Southern Oscillation/El Niño. Mon. Weather Rev. 1982, 110, 354-384. [CrossRef]

18. Kug, J.S.; Jin, F.F.; An, S.I. Two Types of El Niño Events: Cold Tongue El Niño and Warm Pool El Niño. J. Clim. 2009, 22, 1499-1515. [CrossRef]

19. Ashok, K.; Behera, S.K.; Rao, S.A.; Weng, H.; Yamagata, T. El Niño Modoki and its possible teleconnection. J. Geophys. Res. Oceans 2007, 112. [CrossRef]

20. Kao, H.Y.; Yu, J.Y. Contrasting Eastern-Pacific and Central-Pacific Types of ENSO. J. Clim. 2009, 22, 615-632. [CrossRef]

21. Li, G.; Ren, B.; Yang, C.; Zheng, J. Indices of El Niño and El Niño Modoki: An improved El Niño Modoki index. Adv. Atmos. Sci. 2010, 27, 1210-1220. [CrossRef]

22. Dee, D.P.; Uppala, S.M.; Simmons, A.J.; Berrisford, P.; Poli, P.; Kobayashi, S.; Andrae, U.; Balmaseda, M.A.; Balsamo, G.; Bauer, P.; et al. The ERA-Interim reanalysis: Configuration and performance of the data assimilation system. Q. J. R. Meteorol. Soc. 2011, 137, 553-597. [CrossRef]

23. Zagar, N.; Skok, G.; Tribbia, J. Climatology of the ITCZ derived from ERA Interim reanalyses. J. Geophys. Res. Atmos. 2011, 116. [CrossRef]

24. Xie, P.; Arkin, P.A. Global precipitation: A 17-year monthly analysis based on gauge observations, satellite estimates, and numerical model outputs. Bull. Am. Meteorol. Soc. 1997, 78, 2539-2558. [CrossRef]

25. Adam, O.; Bischoff, T.; Schneider, T. Seasonal and Interannual Variations of the Energy Flux Equator and ITCZ. Part I: Zonally Averaged ITCZ Position. J. Clim. 2016, 29, 3219-3230. [CrossRef]

26. Adam, O.; Bischoff, T.; Schneider, T. Seasonal and Interannual Variations of the Energy Flux Equator and ITCZ. Part II: Zonally Varying Shifts of the ITCZ. J. Clim. 2016, 29, 7281-7293. [CrossRef]

27. Mitchell, T.P.; Wallace, J.M. The annual cycle in equatorial convection and sea-surface temperature. J. Clim. 1992, 5, 1140-1156. [CrossRef]

28. Henke, D.; Smyth, P.; Haffke, C.; Magnusdottir, G. Automated analysis of the temporal behavior of the double Intertropical Convergence Zone over the east Pacific. Remote Sens. Environ. 2012, 123, 418-433. [CrossRef]

29. Haffke, C.; Magnusdottir, G.; Henke, D.; Smyth, P.; Peings, Y. Daily states of the March-April east Pacific ITCZ in three decades of high-resolution satellite data. J. Clim. 2016, 29, 2981-2995. [CrossRef]

30. Lindzen, R.S.; Nigam, S. On the role of sea surface temperature gradients in forcing low-level winds and convergence in the tropics. J. Atmos. Sci. 1987, 44, 2418-2436. [CrossRef] 
31. Privé, N.C.; Plumb, R.A. Monsoon dynamics with interactive forcing. Part I: Axisymmetric studies. J. Atmos. Sci. 2007, 64, 1417-1430. [CrossRef]

32. Schneider, T.; Bischoff, T.; Haug, G.H. Migrations and dynamics of the intertropical convergence zone. Nature 2014, 513, 45-53. [CrossRef]

33. Gray, L.J.; Anstey, J.A.; Kawatani, Y.; Lu, H.; Osprey, S.; Schenzinger, V. Surface impacts of the quasi biennial oscillation. Atmos. Chem. Phys. 2018, 18, 8227-8247. [CrossRef]

34. Collimore, C.C.; Martin, D.W.; Hitchman, M.H.; Huesmann, A.; Waliser, D.E. On the relationship between the QBO and tropical deep convection. J. Clim. 2003, 16, 2552-2568. [CrossRef]

35. Garfinkel, C.I.; Hartmann, D.L. The influence of the quasi-biennial oscillation on the troposphere in winter in a hierarchy of models. Part II: Perpetual winter WACCM runs. J. Atmos. Sci. 2011, 68, 2026-2041. [CrossRef]

36. Osprey, S.M.; Butchart, N.; Knight, J.R.; Scaife, A.A.; Hamilton, K.; Anstey, J.A.; Schenzinger, V.; Zhang, C. An unexpected disruption of the atmospheric quasi-biennial oscillation. Science 2016, 353, 1424-1427. [CrossRef]

37. Newman, P.A.; Coy, L.; Pawson, S.; Lait, L.R. The anomalous change in the QBO in 2015-2016. Geophys. Res. Lett. 2016, 43, 8791-8797. [CrossRef]

38. Dunkerton, T.J. The quasi-biennial oscillation of 2015-2016: Hiccup or death spiral? Geophys. Res. Lett. 2016, 43, 10-547. [CrossRef]

39. Diallo, M.; Riese, M.; Birner, T.; Konopka, P.; Müller, R.; Hegglin, M.I.; Santee, M.L.; Baldwin, M.; Legras, B.; Ploeger, F. Response of stratospheric water vapor and ozone to the unusual timing of El Niño and the QBO disruption in 2015-2016. Atmos. Chem. Phys. 2018, 18, 13055-13073. [CrossRef]

40. Babu, S.R.; Liou, Y.A. Tropical tropopause layer evolution during 2015-16 El Niño event inferred from COSMIC RO measurements. J. Atmos. Sol. Terr. Phys. 2021, 212, 212. [CrossRef]

41. Kawatani, Y.; Hamilton, K. Weakened stratospheric quasibiennial oscillation driven by increased tropical mean upwelling. Nature 2013, 497, 478-481. [CrossRef]

42. Lyman, J.M.; Good, S.A.; Gouretski, V.V.; Ishii, M.; Johnson, G.C.; Palmer, M.D.; Smith, D.M.; Willis, J.K. Robust warming of the global upper ocean. Nature 2010, 465, 334-337. [CrossRef]

43. Zhang, C.; Li, S.; Luo, F.; Huang, Z. The global warming hiatus has faded away: An analysis of $2014-2016$ global surface air temperatures. Int. J. Climatol. 2019, 39, 4853-4868. [CrossRef]

44. Allan, R.J.; Gergis, J.; D'Arrigo, R.D. Placing the AD 2014-2016 'protracted'El Niño episode into a long-term context. Holocene 2020, 30, 90-105. [CrossRef]

45. Cha, S.C.; Moon, J.H.; Song, Y.T. A Recent Shift Toward an El Niño-Like Ocean State in the Tropical Pacific and the Resumption of Ocean Warming. Geophys. Res. Lett. 2018, 45, 11-885. [CrossRef]

46. Shi, J.; Fedorov, A.V.; Hu, S. North Pacific temperature and precipitation response to El Niño-like equatorial heating: Sensitivity to forcing location. Clim. Dyn. 2019, 53, 2731-2741. [CrossRef]

47. Capotondi, A.; Wittenberg, A.T.; Newman, M.; Di Lorenzo, E.; Yu, J.Y.; Braconnot, P.; Cole, J.; Dweitte, B.; Giese, B.; Guilyardi, E.; et al. Understanding ENSO diversity. Bull. Am. Meteorol. Soc. 2015, 96, 921-938. [CrossRef]

48. Santoso, A.; Mcphaden, M.J.; Cai, W. The Defining Characteristics of ENSO Extremes and the Strong 2015/2016 El Niño. Rev. Geophys. 2017, 55, 1079-1129. [CrossRef] 